\title{
new
}

\section{perspectives on}

\section{turkey}




\title{
NEW PERSPECTIVES ON TURKEY
}

\author{
Coordinating Editors \\ Çağlar Keyder, SUNY-Binghamton \\ Ayşe Öncü, Boğaziçi University \\ Book Review Editors \\ Reşat Kasaba, University of Washington \\ Hakan Yllmaz, Boğaziçi University
}

\section{Editorial Board}

Günseli Berik University of Utah, Cihan Bilginsoy University of Utah, Korkut Boratav University of Ankara, Haldun Gülalp Boğaziçi University, Fuat Keyman Bilkent University, Şevket Pamuk Boğaziçi University, Fikret Senses Middle East Technical University, E. Ahmet Tonak Simon's Rock College of Bard, Zafer Toprak Boğaziçi University, İnsan Tunalı Koç University.

New Perspectives on Turkey is a series of research papers published biannually by the Economic and Social History Foundation of Turkey (Tarih Vakfi), Valikonağı Cad. Samsun Apt. No. 5780220 Nişantaşı, İstanbul.

See back cover for information regarding submissions and other correspondence.

Subscription rates for 4 issues (2 years, including air-mail postage): Turkey - US $\$ 28$ (US $\$ 10$ single copies); Europe - US $\$ 60$ (US $\$ 15$ single copies); USA and other countries - US $\$ 80$ (US $\$ 15$ single copies) Correspondence relating to subscriptions, advertising, business matters should be sent to Sabâ Altınsay, Tarih Vakfi, Yıldız Sarayı Arabacılar Dairesi, Barbaros Bulvarı, 80700 Beşiktaş, Istanbul (e-mail: saltinsay@tarihvakfi.org.tr).

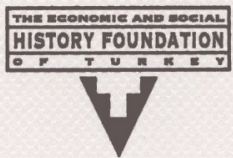

Page Layout: Tarih Vakfi

Printed in Istanbul, December 1999 by Numune Matbaacilik ISBN 975-333-119-3 


\section{CONTENTS}

\section{ARTICLES}

The Politics of Poor Relief in the Late Ottoman Empire, 1876-1914.

$$
\text { Nadir Özbek }
$$

The Poverty of Democracy in Turkey: The Refah Party Episode.

$$
\text { Haldun Gülalp }
$$

The Memoirs of Halide Edip (1884-1964): The Public

Persona and the Personal Narrative.

The Dilemmas of a Search for Cultural Synthesis:

A Portrait of Cemil Meriç as a Conservative Intellectual.

European Union Enlargement and Power Distribution in the Council of Ministers and the European Parliament:

The Case of the Turkish Application.

Fuad Aleskerov, Gamze Avcl, Z.Umut Türem

REVIEW ARTICLE

Mehmedin Kitabl: Challenging Narratives of War and Nationalism.

BOOK REVIEWS

Theodore Spandounes. On the Origins of the Ottoman Emperors.

Edhem Eldem. French Trade in Istanbul in the Eighteenth Century.

Dina Rizk Khoury. State and Provincial Society in the Ottoman Empire: Mosul, 1540-1834.

Lila Abu-Lughod. Remaking Women: Feminism and Modernity in the Middle East. 